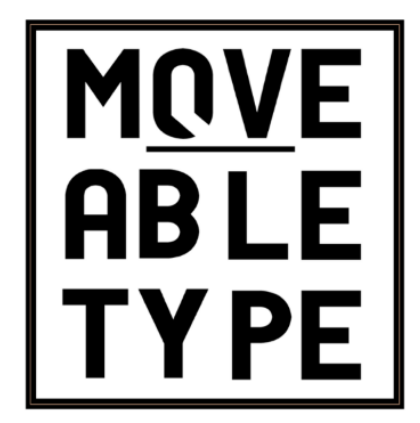

Article: Vague Terrain: Bidonvilles, Run-Down Housing, and the Stigmatisation of (Sub)urban Space In and Around Paris in the 1960s

Author[s]: Jacob Paskins

Source: MoveableType, Vol. 5, 'Mess' (2009)

DOI: $10.14324 / 111.1755-4527.044$

MoveableType is a Graduate, Peer-Reviewed Journal based in the Department of English at UCL.

(C) 2009 Jacob Paskins. This is an Open Access article distributed under the terms of the Creative Commons Attribution License (CC-BY) 4.0https://creativecommons.org/licenses/by/4.0/, which permits unrestricted use, distribution, and reproduction in any medium, provided the original author and source are credited.

\title{
UCLPRESS
}




\section{Vague terrain: bidonvilles, run-down housing, and the stigmatisation of (sub)urban space in and around Paris during the 1960s}

1961, Charles de Gaulle ordered, 'it is important politically and for France that Paris finds the image of a modern city once again. Things must be put in order. ${ }^{1}$ During the 1960s, Paris and its region experienced administrative restructuring and largescale construction work including the boulevard périphérique ring road, the first line of the future Réseau express regional (RER, or regional express railway), and the beginning of five new towns. Gaullist urban planners considered the existing suburbs - predominantly run by Communist mayors - to be a haphazard, sprawling mess that needed to be rationalised. As well as infrastructure work, whole quarters of Paris were demolished and rebuilt, in the desire to create what planners branded 'the Paris of the year 2000.' But it was not only the lack of suburban town planning that was considered a mess at this time: many migrant workers involved in the construction of the modern city lived in bidonvilles (shanty towns). The popular press regularly wrote about the bidonvilles, branding them a filthy mess that needed to be cleaned up, and a shame for Paris. The biggest-selling morning paper in Paris, Le Parisien libéré, referred to bidonvilles in the mid-1960s as: 'un péril pour l'hygiène publique' (a danger for public hygiene), 'ignobles taudis' (revolting slums), 'champs infâmes' (loathsome fields), or 'l'affligeant spectacle' (a distressing spectacle). ${ }^{3}$

This paper examines the language used by the popular press to describe the bidonvilles in the context of the urban transformation of Paris. The stigmatisation of buildings and places by language demonstrates one of the ways through which the built environment is spatially segregated according to wealth, nationality and pollution taboo. Looking at the language of repulsion towards the bidonville shows how physical conditions of dirt, mess and smell are confused with prejudices of race, immigration and manual labour. I analyse the language used to attack the bidonvilles in terms of the notion of abjection: a physical and violent response to what is considered repulsive. The notion of abjection is particularly useful when thinking about the act of degrading habitations so close to a city with ambitious plans for renewal, because the concept, as understood by Julia Kristeva, collapses distinct opposition between subject and object, between what offends and who is offended, and between the centre and periphery of places.

Attracted by work in factories and building construction sites in and around Paris, tens of thousands of foreign workers and their families - mostly Algerian, Italian, Moroccan and Portuguese - migrated to Paris and its surrounding region throughout the 1960s. A combination of low wages, high rents and a shortage of accommodation resulted in significant numbers of workers living in substandard housing. While many shared expensive and cramped hotel rooms, damp and unsanitary apartments or even cellars, tens of thousands of workers and their families found no alternative but 
to live in a bidonville. Located on unused land and among derelict industrial sites, bidonvilles usually comprised temporary housing made from salvaged wood and corrugated iron. General living conditions were terrible: rats abounded and space was overcrowded, with as many as eight people sharing two tiny rooms. ${ }^{4}$ Few huts had basic sanitary facilities: there were no waste disposal facilities, no drainage or running water, and no toilets. ${ }^{5}$

Although bidonvilles grew around the edge of Paris since the late nineteenth century, they rapidly expanded between the 1950s and mid-1970s into more distant suburban towns. Although no official figures exist, Le Monde reported 89 bidonvilles in the Paris region in $1966,{ }^{6}$ while a film commissioned by the French Communist Party stated that there were 119 bidonvilles around Paris in $1970 .^{7}$ In 1966, in the Paris region an estimated 30-35,000 people lived in bidonvilles, and 25-28,000 lived in less formally established micro-bidonvilles. ${ }^{8}$ Around 300 families, including 1,200 children, lived in bidonvilles surrounding rue de la Garenne in Nanterre alone. The bidonvilles around Paris were mostly established along ethnic lines, with specific settlements for Spanish, Portuguese, and Algerians. In the bidonville at La Courneuve, however, the nationalities were very mixed as it was where people who were rejected from their 'ethnic' bidonville tended to gather. The consequence was one of the poorest settlements with the least organisation and the worst conditions. ${ }^{9}$

Records of dreadful living conditions provide a sobering read. Only two water pipes served 3,000 people living in the rue de la Garenne bidonville, resulting in hour-long queues to fill up a tank - the bidon that gives bidonville its name. ${ }^{10}$ Water became the most precious of commodities: as one inhabitant said, "we take more care of water than for oil. ${ }^{11}$ In tiny, dark and often freezing huts with no electricity, illness and light deprivation was common among malnourished workers and children, as was tuberculosis and stomach ulcers. ${ }^{12}$ Improvised shacks and bidonvilles were extremely dangerous places to live. Fire posed the greatest risk and often began due to unsupervised ethanol fuelled stoves. Made primarily from wood, fire could quickly spread through shacks, raging destruction, and fire fighters often struggled to gain access to the narrow and muddy passages of the shanty towns. During the 1960s, scores of bidonville inhabitants, including children, were killed in fires. ${ }^{13}$ 


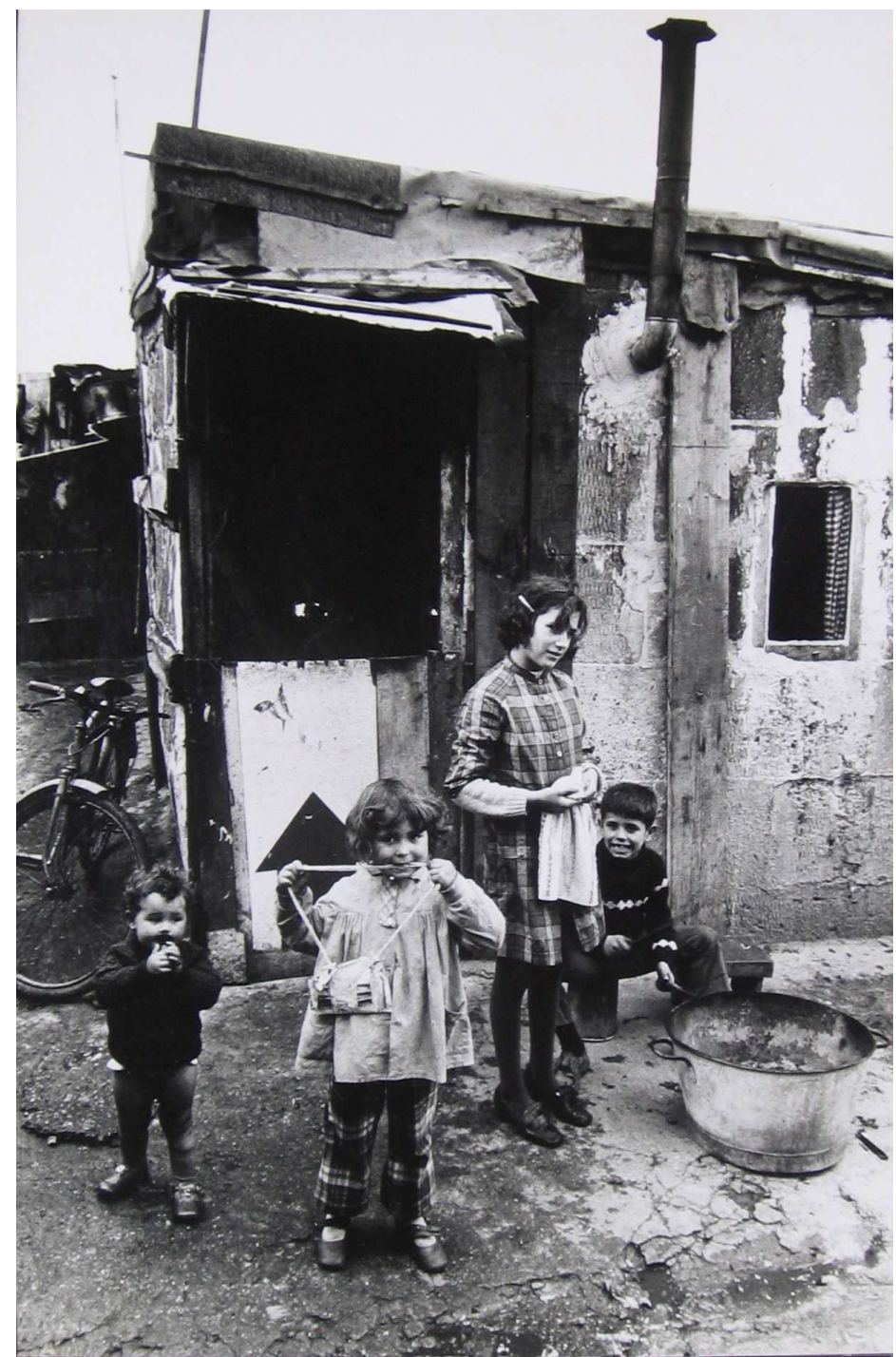

Bidonville, Aubervilliers. C Catherine Cavet, 1970.

\section{Attack on disorder}

Despite the difficult and tragic living conditions of immigrant workers, there was a prevalent attack on rundown housing in 1960s France, led largely by vicious commentaries in the popular press. Usually this was less an attack on the fact that bidonvilles existed, but rather that they caused an unhygienic and filthy mess. The call to destroy bidonvilles often uses as justification the need to eradicate physical dirt and disease. Popular assumptions represented these dense areas of housing as squalid and repulsively foul places, such as in this description from a 1964 article in Le Parisien libéré, which cannot hide its contempt for bidonvilles:

In defiance of all hygiene and safety regulations, 50,000 people live in the suburbs of Paris packed into thirty-eight zones, where squalid groups of huts are tangled up with shells of cars, which serve as a dormitory for a wretched population. ${ }^{14}$ 
An attempt to repulse its readers, much of the language used in this article to describe the bidonvilles relies on disease and defilement metaphors. While 'verrures honteuses pour Paris, qui voudrait devenir la capitale de l'Europe occidentale' translates as 'a shameful eyesore for Paris, which would like to become the capital of Western Europe', the literal translation of verrue is wart or verruca. Similarly, 'cette lèpre de notre société' translates as 'this plague of our society' - shocking enough, but lèpre is literally leprosy, betraying an age-old stigma. ${ }^{15}$ To bring the point home, Le Parisien libéré elsewhere resorts to the analogy of 'cloaques humains,' (human cesspits). ${ }^{16}$

This attack of places branded as dirty shares some historical roots with the concern for hygiene and order in Modernist urban design. Attacking urban dirt and disease formed a central doctrine of many Modernist architecture and urbanism projects. The smooth white walls of buildings by Le Corbusier or Mies Van der Rohe emphasise open space, light and cleanliness as a central law for the design and functioning of the modern city. Le Corbusier's project to demolish central Paris in his Plan Voisin (1923) sought to erase centuries of congested narrow streets that were a perpetually filthy mess. The Modernist movement had a huge influence on a generation of architects and planners. Dense inner-city housing areas in Paris earmarked for urgent attention since the 1930s (Ilots insalubres - housing deemed unfit for habitation) but largely left unaltered, remained a target for modernist architects and urbanists in the sixties. With concerns for heritage taking second place, ilots insalubres were only very occasionally restored and more commonly completely demolished. Modernist tendencies also manifested themselves in Paris during the 1960 s with a wide scale project to clean - or 'whiten' - 13,361 public buildings and historic monuments, and 73,013 residential buildings. ${ }^{17}$ One of the most famous and visited monuments in the world, the Arc de Triomphe was covered in scaffolding in March 1965 in preparation for major restoration and cleaning with compressed water jets. ${ }^{18}$

For all its desires to clear away mess, it is apparent that the Modernist discourse of urban hygiene is often used to distract from social problems of poverty and housing shortages. Areas of Paris such as Ménilmontant, with a population density of 760 inhabitants per hectare in the mid-1960s, had long been classified as an ilot insalubre. ${ }^{19}$ The solution offered was total demolition and a displacement of much of the working-class population to suburban housing estates. ${ }^{20}$ Incidentally, the '4000' at La Courneuve is an Habitation à Loyer Modéré (HLM) housing estate originally financed by the City of Paris housing authorities, not the suburban town of La Courneuve, and is the most visible sign of an intentional displacement of the population of Paris. ${ }^{21}$ Modernist architecture could never really clean up the city because cleanliness was never the sole target of urban renovation. The first critics of Modernism understood that the project to rebuild the city used hygienist rhetoric as an excuse to clear inner-city run-down housing and replace it with office blocks and large shops. Historian and ardent conservation lobbyist Louis Chevalier describes the project to whiten Paris monuments as 'most detestable, because [it is] the most costly 
and useless, and doubtless [the] most dangerous'. ${ }^{22}$ This was dangerous not just for the stonework, but because the desire to clean up the city is an excuse to eradicate any trace of everyday human activity, such as small-scale Parisian industry and food markets. Plans to 'whiten' physical dirt, and to clear away haphazard street layouts and dense housing in Paris mirrored the desire to eradicate the smell and disorder of bidonvilles.

In a Paris experiencing a deep clean and radical makeover after the years of occupation, and the ravages of the Algerian war which was being fought on the streets of the capital in the early 1960s, the existence of mess and dirt seemed to hit a raw nerve. Interviews with inhabitants of bidonvilles reveal that something as mundane as wearing dirty shoes was an instant social distinguisher in Paris. ${ }^{23}$ Dirty shoes not only suggested the person wearing them lived in a muddy bidonville, but it seemed to discriminate the individual as somehow less human, or at least not a part of Parisian culture or society. Yet the testimony of Yasmina, the 11-year-old daughter of a Moroccan construction worker living in La Folie, reveals it is less visible dirt than the fear of dirt that is the cause of hate. Despite the fact she had never before arrived at school covered in mud, Yasmina explains that girls at school tell her they think she is surrounded by rats, is dirty, and does not wash simply because she lives in the bidonville. The schoolgirls say Yasmina is not like them as they live in a building and that if she did live inside they would play with her. Furthermore, it seems the girls' discrimination is purely against the bidonville rather than Yasmina's ethnicity: they say they play with Moroccan girls, but only those who live in buildings. ${ }^{24}$

Local residents living near to bidonvilles interviewed for the Sept jours du monde television programme in 1964 complain of the noise and smell of the neighbouring shanty town, and one woman says the inhabitants of the bidonville make public transport stink. ${ }^{25}$ It is perhaps not unreasonable to assume workers living in a bidonville did have a strong body odour - after all, only two water taps served 3,000 people in La Folie bidonville in Nanterre, and drinking water took priority over baths. But for many outside, the apparent mess and smell of the bidonvilles became a sign of danger to hygiene and the order of the state: as Dominique Laporte has argued, smell symbolises human's animal characteristics, which 'civilisation' seeks to eradicate. ${ }^{26}$ Monique Hervo's diary of her years as a volunteer in Nanterre records a tale of an Algerian construction worker in his fifties who, in poor health after years of digging foundations by hand, paid a visit to the local social security office. There, the employee at the counter at first refused to serve the man, then made it clear to the others in the queue that the client's papers were a filthy mess: 'The bicot's [a derogatory term in French for an Arab] papers are dirty.' Openly insulting the man, she then told him he smelt bad. Terrified, the man certainly was not in a position to explain his papers were messy because the previous day, during an aggressive search, Police had torn his documents to pieces and thrown them in the mud of the bidvonille. Desperate, the man had carefully glued the papers back together. ${ }^{27}$ 
'Civilisation,' writes Laporte, 'despises odor and will oust it with increased ferocity as power strives to close the gap between itself and divine purity. ${ }^{28}$ Understood this way, the attack on the smell of the bidonvilles is a form of 'imperialism' that seeks to efface the presence of dense groups of foreign workers that do not enjoy access to clean running water. The language used to attack mess and smell entwines the human behaviour and characteristics of people who live in bidonvilles with the conditions of the bidonville itself, resulting in the situation where people who live differently are excluded from ordinary sociability. The bidonville becomes a site that, as both built form and cultural phenomenon, threatens French identity.

\section{Abjection and urban space}

To help understand the hygienist obsession of Modernist planning, and indeed interpret the use of space in post-industrial cities, many urban theorists of the last couple of decades have embraced social-anthropologist Mary Douglas's idea that dirt is 'matter out of place. ${ }^{29}$ In this conception, the idea that something is unhygienic lies in the fact it falls outside a boundary that establishes what is culturally accepted as clean. Douglas's framework of 'matter out of place' relies on the assumed existence of fixed boundaries, which separate the clean from the dirty, the pure from the un-pure. In the real city, however, boundaries are often far from concrete: they can be fluid, and more often than not are created by fears of danger, dirt or class. It could be argued in this light that the desire to clear up Ménilmontant was less due to lack of sanitation than the fear of the concentration of a potentially revolutionary population in an area that was the stronghold of the 1871 Commune. Like Douglas, literary and cultural theorist Julia Kristeva is also interested in the conception of dirt as part of a classification system. Her notion of the abject is particularly useful when considering the question of urban cleanliness because her understanding of the ambiguity of boundaries lends itself to a theoretical framework rooted in spatiality. Interpretation of space is an important characteristic of an historical and cultural analysis of the built environment.

In Kristeva's understanding of the individual's experience of abjection, she notes that 'abject and abjection are my safeguards. ${ }^{, 30}$ The body responds to repulsion with reflexes such as sickness, which intends to protect the individual from what is feared. We find language of abjection in Le Parisien - words that correspond to the body's physical response to repulsion, creating a separation from the reader and the bidonville described. The description 'lamentables "dépotoirs humains", (lamentable human dumping ground) refers to the human's reflex to cry to protect the eyes, while '[le] répugnant bidonville de Nanterre' (the repugnant Nanterre bidonville) draws on the verb répugner, to be repelled or made to feel sick. ${ }^{31}$ This language is even more emotive because it is found in an article on the death of children in a fire. 
The label 'human dumping ground' was taken to the limits at La Folie where some non-bidonville residents literally used the land as an illegal rubbish dump. Lakhdar, a qualified builder living in the bidonville, describes how a lorry dumped used fish crates in front of the huts that served as the local grocery and butcher. ${ }^{32}$ Adding to the already miserable conditions, this behaviour shows utter contempt for the health of the people living in the bidonville - those dumping rubbish at La Folie saw its inhabitants as the garbage of society.

Abjection attempts to create boundaries in order to marginalise groups. The language of disgust of the dirt of the bidonvilles, and the act of using them as a tip, is an attempt to establish distance through repulsion. But abjection is not simply aversion. The abject begins to collapse fixed boundaries and the clear-cut oppositions between subject and object: Kristeva writes it is "not the lack of cleanliness or health that causes abjection but what disturbs identity, system, order. What does not respect borders, positions, rules. The in-between, the ambiguous, the composite. ${ }^{33}$ Abjection shows that a distinction between the clean and unclean is not made because something falls on the wrong side of a boundary because the boundary might not even be there.

Understanding the language of the press as language of disgust - as abjection suggests that the problem might lie within the source that feeds this hate, for 'the subject [...] finds the impossible within; when it finds out that the impossible constitutes its very being, that it is none other than abject. [...] There is nothing like the abjection of self to show that all abjection is in fact recognition of the want on which any being, meaning, language, or desire is founded. ${ }^{34}$ If the abject breaks down the fixed distinction between subject and object, between the inside and outside of the body, it also collapses the division between the public and private; order and mess; and the centre and periphery. This last point has important implications for the relationships between inhabitants, urban and suburban space.

To this day many regard the suburbs of Paris with fear and suspicion. At the beginning of his 1989 journey through the banlieue, François Maspero describes the common assumption that:

$[\mathrm{M}]$ any Parisians saw the suburbs as a shapeless muddle, a desert containing ten million inhabitants, a series of indistinct grey buildings: a circular purgatory, with Paris as paradise in the middle. The suburbs were something 'all around'. A wasteland. A land for wasting souls. ${ }^{35}$

When thinking about spatial divisions and exclusion in the city, Kristeva forces us to acknowledge that what repulses and offends is neither physically detached from us, nor spatially divided. But despite being aware the bidonvilles were so close to Paris, the 1960s press attempted to distance the capital from the feared vagaries of the suburbs. In 1968, Le Monde noted that the suburban bidonvilles had become a 'veritable ghetto cut off from outside. ${ }^{36}$ These places were not only perceived to be 
dirty and dangerous places, but were considered to be somewhere else, and excluded from society. Vagueness of language creates spatial segregation in the territory around Paris.

\section{Vague terrain}

Texts referring to the location of bidonvilles, including the press, often use a general term 'zone' to mean the suburbs of Paris. The use of the word 'zone' seems to cause much confusion: it is used to mean unused or derelict brownfield land, such as in the novel Derrière la vitre, in which Robert Merle's narrator describes the unbuilt land at Nanterre as a 'zone, ${ }^{37}$ and to this day 'zone' in French is used to name an area where people would rather not go. Sometimes the 1960s press, ignorant of the history of the boundaries of Paris, mistakenly and vaguely refer to suburban areas as being part of Paris's 'former zone. ${ }^{38}$ As the map shows, in reality, the 'zone' of Paris refers only to the zone non aedificandi - the belt of land around Paris where fortifications stood until the 1920s, and on which it was forbidden to construct buildings.

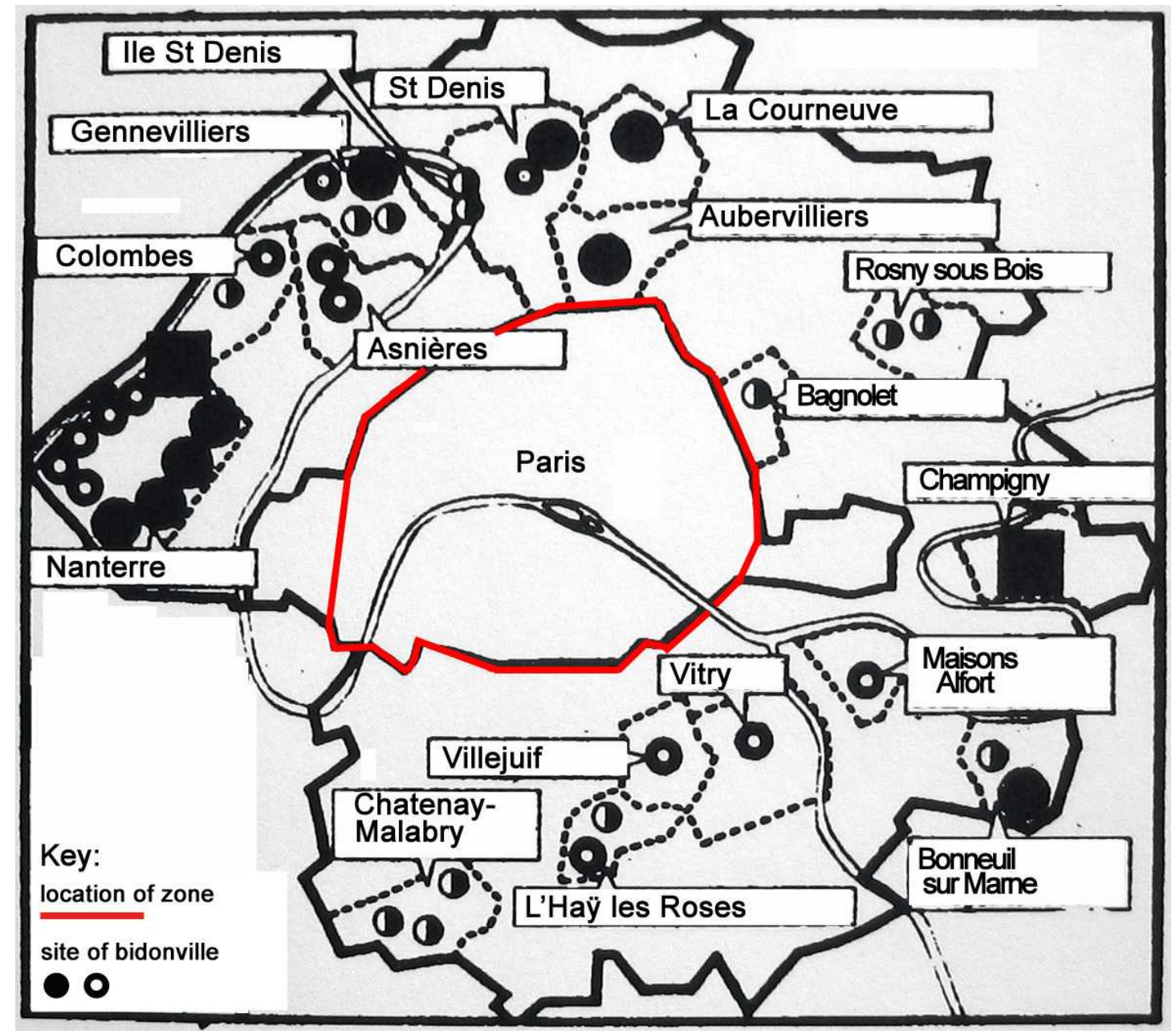

Map of the location of the former 'zone' on the periphery of Paris, and surrounding towns that had at least one bidonville in 1965. 
The confusion is that this 'zone', which is 390 metres wide and $35 \mathrm{~km}$ in circumference, did once contain a number of bidonvilles, but by the 1960s these had mostly all been cleared. After attempts to rid the original 'zone' of inhabitants for decades, the last 'zoniers' were expropriated in 1970 to make way for the final section of the boulevard périphérique at Porte de Champerret. ${ }^{39}$ This mistaken use of terminology may also come from journalists' confusion with planners' jargon. In the 1965 Schéma directeur d'aménagement et d'urbanisme de la région de Paris planning document, for example, town planners divide the Paris agglomeration into six 'zones' of secondary towns, rural and forest areas. In any case, to use the term 'zone' as a sweeping generalisation of the towns of the suburbs creates spatial exclusion in the territory, and is an insult to those living there. It assumes the suburbs are a disused void or dangerous places designated to house the poor.

For authorities such as the police, the social security and municipal housing office, inhabitants of bidonvilles posed problems for rigid systems of bureaucracy. Accounts by people who tried to obtain identity cards or apply for housing show that some civil servants refused to help them, on the grounds that the address of the bidonville was not a fixed address, or worse, simply did not exist:

La Folie is not an address! The bidonville doesn't exist. ${ }^{40}$

There is no number 127 rue de la Garenne. This address doesn't exist. ${ }^{41}$

And so as you say 127 rue de La Garenne, they say "no". ${ }^{42}$

Bidonville? Never! We never deliver permits or ID cards there. Bidonvilles don't exist. It's just a post box, isn't it? For us, those people don't exist. ${ }^{43}$

The lack of what the police and town hall authorities defined as a 'fixed address' meant it was impossible for a builder living in the Nanterre bidonville to obtain a resident permit for his wife. ${ }^{44}$ Having no official address increased the hardship for workers even for those with legal work permits and those who contributed to insurance payments. When Mohammed, a builder from Morocco, had an accident at work he was unable to make an insurance claim simply because the inspector did not honour his appointment at Mohammed's bidonville home. ${ }^{45}$ Lacking a more privileged address caused a vicious circle of bureaucracy: one qualified builder living in a bidonville was unable to buy somewhere to live because he lacked access to credit, as credit was only available to those possessing an official address to guarantee the loan. ${ }^{46}$ These accounts show that abjection tries to distance the very physically present bidonville - and its inhabitants - to such a level that it no longer exists in the mind. It is a no-where. 


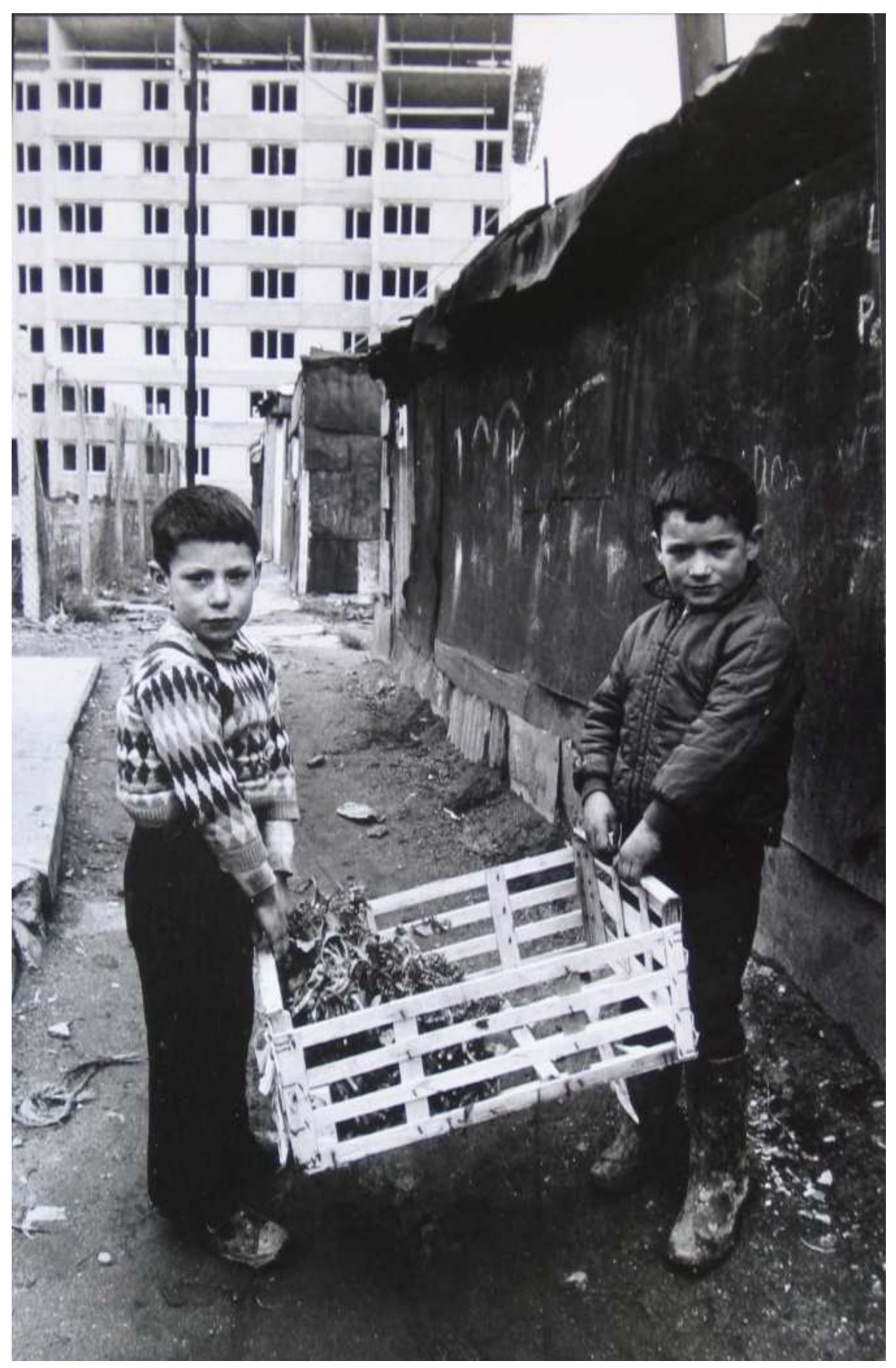

Bidonville, Aubervilliers. (C) Catherine Cavet, 1970.

The nomenclature of bidonvilles by the popular press also establishes spatial division by the stigmatisation of places. Beyond the perceived filth of the bidonvilles, the language of Le Parisien hints at an assumed immorality of the poor workers inside. It writes of 'Taudis - destructeurs de toute vie familiale décente' (slums - destructors of all decent family life), ${ }^{47}$ and gives the impression that the foreign bidonville inhabitants are dangerous to the local French population, the latter being, the paper claims, subjected to overcrowding and always watching out for danger. ${ }^{48}$ Although 
taudis historically has been used to describe a small workshop or an attic, since the eighteenth century its meaning is an exclusively pejorative word for housing in a bad condition. ${ }^{49}$ In my own writing I attempt to avoid the term 'slum'. Similar to taudis, it is all too easy to use the word slum casually, yet the use of this word to mean informal settlements or run-down housing risks creating a value judgment that connects poor housing with dirty and dangerous residents. ${ }^{50}$ But in the sixties, this was exactly what Le Parisien libéré wanted to do.

The press also describe bidonvilles as 'Cours des Miracles,' using the term once given to dense and poor housing areas in medieval Paris. ${ }^{51}$ 'Cours des Miracles' were feared as enclosed communities, housing destitute people, beggars, thieves, prostitutes and frauds. Rookeries in London - the dense working class housing areas of central London, such as those of St Giles, cleared in the mid-nineteenth century to make way for New Oxford Street - had a similar reputation. (The word rook in the sixteenth century was synonymous for cheat or swindler). The press uses the term 'Cours des Miracles' as a synonym for a place housing people rejected by a society which brands them as dangerous and conniving. For Le Parisien, physical appearance and hygiene is synonymous with morality: their descriptions suggest crumbling shacks are likely to be as dirty and diseased as the behaviour of those who lived inside. The call to destroy the bidonvilles, then, was a thinly disguised attack on the poor and foreign workers they housed.

\section{Horrors next door}

Despite the emotive response to the bidonvilles, understanding the language of repulsion in terms of abjection suggests apparent disgust is in fact close to complicity. Kristeva notes 'abjection is elaborated through a failure to recognize its kin. ${ }^{52}$ In these terms, whether knowingly or not, the centre of Paris depends on its periphery. Despite the constant attack by politicians and the press on the perceived threat of suburban bidonvilles, their continued existence showed the 'civilisation' of Paris depended greatly on what surrounds it, however repulsive. The suburbs are where the workers live, where the cars in factories are made; they are where the motorways begin to tear apart the land, and where the waste of the city is continually dumped. Without the suburbs, and those who live there, Paris would be an even more ruinous mess of rubbish, dirt and congestion.

In 1965, Le Monde published a series of articles on the bidonville problem, but, in stark contrast to the coverage in Le Parisien, they highlighted the causes for the existence of shanty towns, rather than directly attacking them. Possible origins of the problem included the general housing shortage, low wages for migrant workers, the colonial wars, and employers who did not take care of their workers. Le Monde makes clear that the bidonvilles themselves are not the problem: the real crisis is the 
existence of poverty in the super-rich industrial world. It is a view shared by a building labourer, Lakhdar, who, although almost illiterate, had a clear political consciousness and expressed dismay at the hypocrisy of a country that invites workers then badly treats them and criticises them for their living conditions. ${ }^{53}$

If the problem is the not bidonville itself, but the capitalist society that tolerates extreme poverty just a ten-minute drive away from the boutiques of the Champs Elysées, we have to acknowledge that those who enjoy the benefits of the cheap work force who lived there are inseparable from their existence - that includes everyone who had a car, drove on new roads, used the RER, went to a new school or who used electricity produced by a newly-built nuclear power station. Understood this way, the bidonville breaks the binary opposition between distant, dangerous and dirty 'slums' and the so-called civilisation of Paris. The effort by the popular press to create spatial exclusion within urban territory through language, then, is an attempt to distance something that is too close for comfort.

A further example of the spatial breakdown between the 'progress' of the modern city, and the 'offence' of dilapidated wrecks is found in television footage of the new Maison de la Radio in Paris. ${ }^{54}$ Here, what causes offence is not even in the suburbs but in the heart of the capital.

\section{Link to video of 'La Maison de la Radio,' (Edition spéciale, 05.09.1963) http://bit.ly/5YuD2H}

The shots show a startling contrast between the aluminium and glass architecture of the radio centre, and the rundown wooden shacks just across the street in front on the banks of the river. The narrator shrugs this off as 'mauvaises habitudes' (bad habits) as if it were a natural condition. It shows the complacency of the modern state on its dependency of the poor. Here the modernity of this architectural showcase stands out against much of the rest of Paris. Similarly, asked in an interview whether he has electricity, a construction worker living in La Folie notes that modern infrastructure now exists everywhere, but completely excludes the bidonville: 'Electricity, where? Tell me? There's none. I find electricity on the street but not at home, and yet it's not far from us! ${ }^{55}$ The same man notes with irony that tourists should come and visit the bidonvilles to see what France is really like - only then will the government start to worry about the problem. ${ }^{56}$

Once again, the identity of the 'order' of Paris and the 'mess' of the run-down housing are closely entangled. A continual paradox of modernity, the comfortable life of Parisians depends on the workforce that lives in the shanty towns, and is complicit with the ongoing existence of misery. As Kristeva notes:

I experience abjection only if an Other has settled in place and stead of what will be "me." Not at all an other with whom I identify and incorporate, but an Other who precedes and possesses me, and through such possession causes me to be. ${ }^{57}$ 
The presence of a large population of workers who suffer racial discrimination, few social benefits and union rights is all the more haunting because is so readily taken for granted and can so easily be made invisible. In Kristeva's terms, then, our dependency will only become apparent when our needs are no longer met.

\section{The long road to nowhere}

Because of society's unashamed complicity, it is hardly surprising that the government plans to eradicate the bidonvilles in the 1960s were constantly postponed. The growing population of foreign workers and children living in dangerous and unsanitary conditions created a national scandal, and politicians promised to eradicate all trace of the bidonvilles. All sides of the political spectrum seemed to agree bidonvilles were unacceptable, especially due to the number of children living there and the high levels of malnutrition and disease. In the Communist backed film Les Immigrés en France, a teacher explains that children who live in the bidonvilles are behind in their progress because of language problems and their poor living conditions. The children are simply unable to do homework where they live, where people are forced to cook and wash clothes outside, surrounded by mud, and in freezing winter temperatures. In the same film, a doctor claims half of the tuberculosis cases in his hospital are 'North African' patients. (The vagueness of the extremely commonly used term 'North African', here used by a doctor in a Communist film, shows it was not just the right-wing popular press that casually ignored the provenance of Algerians and Moroccans). He says it is not possible to contain infection if people live in overcrowded bidonvilles - 10,000 'North Africans' were living in Argenteuil alone. No doubt a message to the government, the doctor insists the medical costs caused by such conditions far outweigh the cost to build new housing. ${ }^{58}$ 


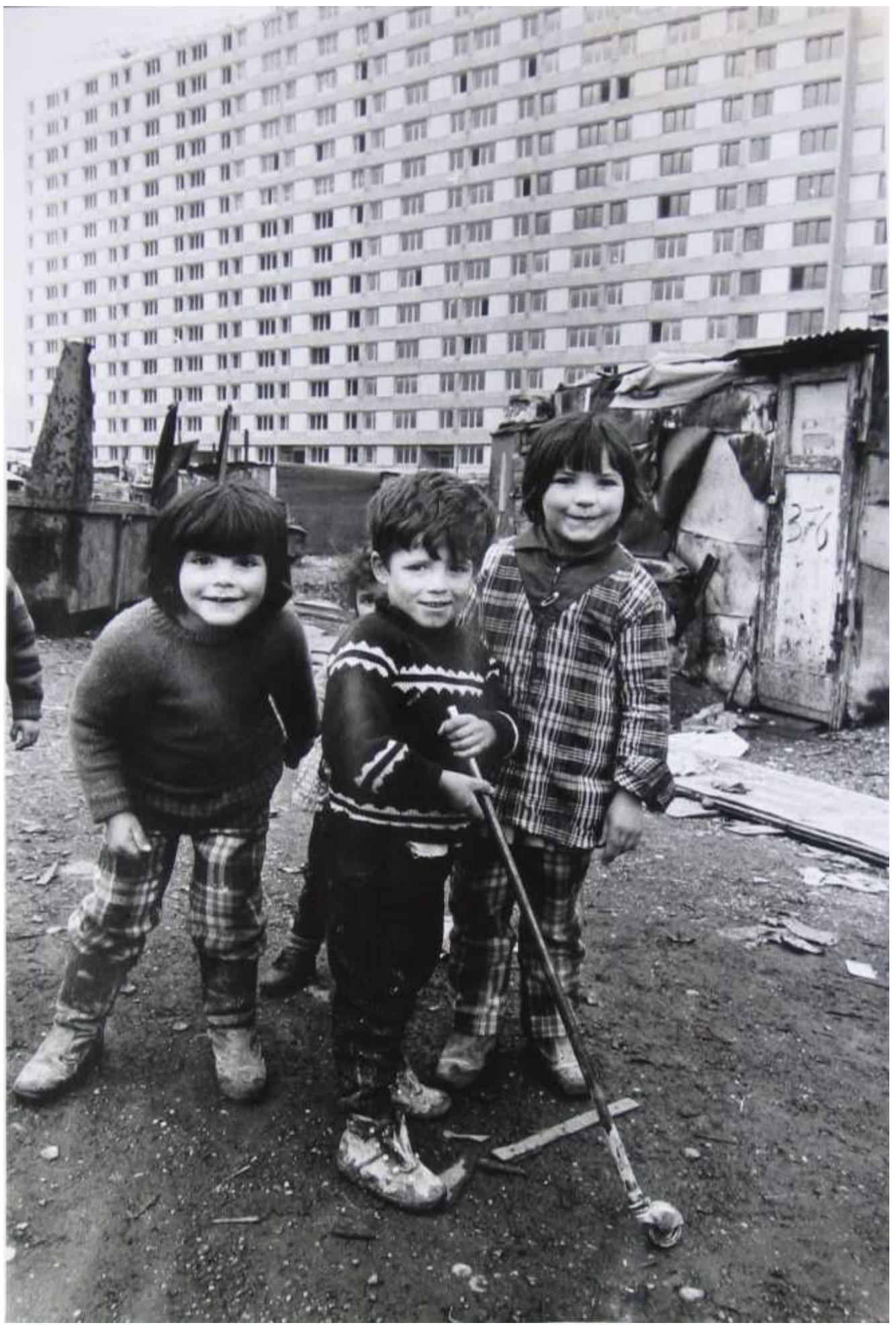

Bidonville, Aubervilliers. (C) Catherine Cavet, 1970.

In December 1964, the minister of Economy and Finance Michel Debré announced plans to end this phenomenon for good. He promised that the Caisse des dépôts et consignations (deposit and consignment office) would construct very affordable 
housing to replace bidonvilles. ${ }^{59}$ The law of 14 December 1964 set in place procedures to facilitate urban construction projects by means of expropriation of land containing 'insalubrious housing' commonly known as bidonvilles. Crucially, the law states that any expulsed inhabitants are guaranteed a permanent residence. The enormous pressure this would place on an already stretched housing stock meant implementing the law was a lot to ask for many towns. As authorities found it cheaper to do nothing, the consequence was the continued existence of bidonvilles and a blame game of who should take responsibility for re-housing inhabitants. In the case of the bidonvilles at Chévilly-Larue and 1'Haÿ-les-Roses, located on land required for the new Rungis market railway depot, the market representatives claimed it should be the Prefecture's responsibility to provide housing, while the Prefecture thought the market should be responsible. ${ }^{60}$ In January 1966, the 1964 law was changed to make it easier to clear bidonvilles, with a clause that justified expropriation for the provision of public housing, rather than for reasons of hygiene. To make the return to expropriated land even harder for evicted inhabitants, the amendments authorised that any land surrounding bidonvilles could also be expropriated, including property of any legal landowners. ${ }^{61}$ The 1966 law also proposed the construction of an additional 15,000 HLM housing units on top of the 8,000 already pledged to 'absorb' the bidonville population, and the target date to eradicate all bidonvilles was reduced to five years, from the original ten. ${ }^{62}$ Rather than showing increased concern for the living conditions of bidonville inhabitants, the real winners of this legal amendment seems to be private property speculation and construction companies, who could henceforth obtain contracts to build on expropriated land, meaning local authorities were no longer obliged to develop the land with public finance. ${ }^{63}$ Some of the operations to eradicate bidonvilles were particularly drastic and showed little consideration for the displaced population. When Michel Maurice-Bokanovski, mayor of Asnières, announced plans to redevelop land on which a bidonville was situated, the evicted inhabitants kept returning in greater force until the armed CRS police were called in to drive the residents out. The police then burnt down the shacks to prevent any further settlement and enable the land to be cleared for a municipal housing development. ${ }^{64}$

Despite the increased powers, the Plan Debré was slow to have any effect, and bidonvilles remained as a large-scale problem during the early 1970s. An example of putting off the problem was the expulsion of a group of 157 families from a Nanterre bidonville on 25 May 1967. After an appeal, M. Rouanet de Vigne-Lavit, vicepresident of the Seine departmental court granted a year's grace before final eviction. ${ }^{65}$ If the inhabitants resisted eviction it was less out of an enjoyment of the terrible conditions of the bidonville than the limited choice of where to live next, with lengthy waiting lists and high rents for social housing. The judge's decision to allow the families to stay only temporarily put off the problem - and it is hardly a coincidence that his decision took pressure off the local housing authorities to find replacement accommodation. For all the government's promises, bidonvilles still existed in the 1980s, and in different ways many thousands of migrants in Paris are 
still poorly housed. ${ }^{66}$ The fact so little was done in twenty years, despite encouraging arrival of workers characterised the laissez faire politics of post-war France. ${ }^{67}$ Inhabitants of bidonvilles were constantly told that the encampments would be destroyed in the next couple of months, yet despite the occasional aggressive demolitions by the police, the largest remained for the best part of two decades. ${ }^{68}$

The notion of abjection forces us to confront the relationship of the individual subject within the city. A framework that is particularly helpful for analysing the spatiality of cities, Kristeva's concept challenges the assumption that subject and object are separate. More than simply hygienist rhetoric on dirt, or defence of French identity, the attack by the popular press on bidonvilles was a way of distracting attention from the social injustices of the pursuit of economic growth. Refusing to acknowledge the role the inhabitants of the bidonvilles played in powering the wealth of France, the press turned the mirror, focussing blame on individuals living in the most dreadful conditions for being a blot on the landscape. Abjection suggests that such attacks reveal a nagging fear and fascination - and complicity - for something unavoidably close to home: the fear of the bidonvilles becomes perverse as this is repulsion of something that is desired. This article has tried to show how language is used to separate the periphery of the city from the centre, and to stigmatise urban space as a desire to create the illusion that the wealth and order of Paris has nothing to do with the poverty and 'mess' of the suburbs. Understanding these tactics in terms of abjection begins to break down projected hierarchy of urban space, and in turn this helps unravel the ambivalence of politicians and the media towards the existence of the bidonvilles. After all, like nuclear waste today, it is easier to pretend some things are far away rather than trying to find a solution to the problem.

As a brief epilogue to its ever manipulative and paradoxical remit, it is interesting to note that the popular press was not always hostile to what the planners considered to be incurable eyesores. When the combined forces of bulldozer, developer and highrise flat threatened old areas of Paris, the press kicked into nostalgic mode in order to defend familiar but rundown districts, first proclaiming scandal and then tragedy. Most famous is the demolition of the central markets Les Halles, mooted throughout the sixties, and finally carried out in 1974, which would drive away centuries of noise, congestion, broken crates of vegetables and thousands of market workers. The fear of the demolition of Paris, then, is in fact the fear it will be cleaned of mess - the traces of its past and identity.

\title{
JACOB PASKINS
}

\author{
Jacob Paskins is a doctoral candidate in Architectural History \& Theory at the \\ Bartlett School of Architecture. He is a founding member of the Autopsies \\ Group, a research project in the UCL Film Studies Space.
}


${ }^{1}$ Robert France, Le scandale de Paris (Paris: Grasset, 1971), pp.168-69. Unless otherwise stated, all translations are my own.

2 'Trente-huit bidonvilles dans la Seine', Le Parisien libéré, 12 December 1964, p.3.

3 'Dans un baraquement du répugnant bidonville de Nanterre, 3 enfants ont été brulés vifs', Le Parisien libéré, 26 March 1966, p.2.

${ }^{4}$ Interview with Latifa, daughter of a construction labourer, in Monique Hervo and Marie-Ange

Charras, Bidonvilles: l'enlisement (Paris: François Maspero, 1971), p.178.

${ }^{5}$ Interview with Aïcha and Mohammed, builders, in Hervo and Charras, Bidonvilles, p.39.

${ }^{6}$ Pierre Trey, 'Bidonvilles et Sous-Prolétariat Urbain', Le Monde, 8 August 1966, p.18.

${ }^{7}$ Les Immigrés en France, dir. Robert Bozzi (1970).

8 'L'opération "anti-bidonville" du gouvernement doit permettre de reloger, en 3 ans, plus de 60000 personnes', Le Parisien libéré, 26 March 1966, p.2.

${ }^{9}$ Interview with a worker from Secours social charity in 'Les travailleurs étrangers en France', an episode of the radio programme, Grandes enquêtes on Inter-Varitétés, 20 April 1967.

${ }^{10}$ Robert Merle, Derrière la vitre (Paris: Gallimard, 1970), p.22. See, also, an interview with Khadidja, wife of a construction worker, in Hervo and Charras, Bidonvilles, p.153, who says that queuing for water usually takes between an hour to an hour and a half.

${ }^{11}$ Interview with Mohammed, building worker, in Hervo and Charras, Bidonvilles, p.35.

${ }^{12}$ Interview with a doctor in Les Immigrés en France. See also Merle, Derrière la vitre, p.98.

${ }^{13}$ A cursory selection of victims of bidonville fires includes M. Fellah Hocine, 28 years old, killed along with fifteen homeless people ('Incendie dans le bidonville de Nanterre: un mort; quinze sansabri', France-Soir, 3 April 1962, p.8); 100 people evacuated from La Courneuve bidonville without injury (“A La Courneuve incendie dans un "bidonville", Le Parisien libéré, 3 May 1966, p.16). See, also, the list of bidonville fires in Hervo and Charras, Bidonvilles, pp.322 \& 326.

14 'Trente-huit bidonvilles dans la Seine', Le Parisien libéré, 12 December 1964, p.3.

15 'Trente-huit bidonvilles dans la Seine', Le Parisien libéré, 12 December 1964, p.3.

16 'Dans un baraquement du répugnant bidonville de Nanterre, 3 enfants ont été brulés vifs', Le Parisien libéré, 12 March 1966, p.2.

17 '77 millions pour nettoyer la Madeleine', France-Soir, 8 September 1962, p.11.

${ }^{18}$ See Le Parisien libéré, 26 March 1965, p.5; 'Les Echafaudeurs' segment of the television series Les coulisses de l'exploit, 19 August 1965, shows the erection of the scaffolding; the feature film Un Homme et Une Femme, dir. Claude Lelouche (Les Films 13, 1966) shows a silhouette of scaffolding on the Arc de Triomphe from the Champs-Elysées; 'A propos d'une refection. La singulière histoire de l'Arc de Triomphe' sequence from the newsreel Les Actualités Françaises, distributed 11 August 1965, shows the restoration process underway.

${ }^{19}$ Guide bleu Paris (Paris: Hachette, 1972), p.411.

20 'Ménilmontant-Belleville' episode of television documentary series Mémoires d'un vieux quartier, 7 June 1965

${ }_{21}$ 'La Courneuve', Techniques et Architecture, 22 (1962, special issue on HLM de la Ville de Paris), pp.86-87.

${ }^{22}$ Louis Chevalier, The Assassination of Paris, trans. by David P. Jordan (Chicago; London: University of Chicago Press, 1994), p.221.

${ }^{23}$ See for example interviews with construction workers Lahoussine (p.188) and Tahar (p.246), and

Lafita, the 16-year-old daughter of a building labourer in Hervo and Charras, Bidonvilles, p.177.

${ }^{24}$ Interview with Yasmina, in Hervo and Charras, Bidonvilles, p.144.

${ }^{25}$ Interviews in 'Ils sont trois millions de travailleurs étrangers en France' episode of television magazine programme Sept jours du monde, 12 June 1964.

${ }^{26}$ Dominique Laporte, History of Shit, trans. Rodolphe el-Khoury and Nadia Benabid (Cambridge, Mass.; London: MIT Press, 2002), p.83.

${ }^{27}$ Diary entry of 11 October 1961, Monique Hervo, Chroniques du bidonville: Nanterre en guerre d'Algérie (Paris: Seuil, 2001), p.195.

${ }^{28}$ Laporte, History of Shit, p.83.

${ }^{29}$ Mary Douglas, Purity and danger: an analysis of concept of pollution and taboo (London: Routledge, 2002). Urban histories that refer to Douglas's text include, for example, Adrian Forty, Objects of Desire: Design and Society since 1750 (London: Thames and Hudson, 1986), Chapter 7; Donald Reid, Paris Sewers and Sewermen: Realities and Representations (Cambridge, Mass.: Harvard University Press, 1991); Ben Campkin and Rosie Cox (eds.), Dirt: New Geographies of Cleanliness \& Contamination (London: IB Tauris, 2007). 
${ }^{30}$ Julia Kristeva, 'Approaching abjection', in The Portable Kristeva, ed. by Kelly Oliver (New York: Columbia University Press, 1997), p.230.

31 'Dans un baraquement du répugnant bidonville de Nanterre, 3 enfants ont été brulés vifs', Le

Parisien libéré, 26 March 1966, p.2.

${ }^{32}$ Interview with Lakhdar, in Hervo and Charras, Bidonvilles, p.87.

${ }^{33}$ Kristeva, 'Approaching abjection', p. 232.

${ }^{34}$ Kristeva, ‘Approaching abjection', p. 232.

${ }^{35}$ François Maspero, Roissy Express, a Journey Through the Paris Suburbs, trans. Paul Jones. (London; New York: Verso, 1994), p.16.

36 'Veritable ghetto coupe de l'extérieur', in Michel Marcelle, 'Ahmed l'Algérien, Television review', Le Monde, 12 January 1968 (in the television listings for 18 January 1968).

${ }^{37}$ Merle, Derrière la vitre, p.18.

${ }^{38}$ See, for example, B. Delprach, 'L'ancienne “zone”, où s'entassent 50,000 habitants, ne fait que croître', Le Parisien libéré, 26 March 1966, p.2.

${ }^{39}$ Les fortifs et la Zone, dir. Claude Vergé (documentary, 1988).

${ }^{40}$ Comments of a police brigadier at Nanterre police station, 6 April 1961, in Hervo, Chroniques $d u$ bidonville, p.117. See, also, the interview with Lahoussine, in Hervo and Charras, Bidonvilles, p.189.

${ }^{41}$ Words of officers in Nanterre police station, 3 September 1961, in Hervo, Chroniques du bidonville, p. 157 .

${ }^{42}$ Interview with the sister of Mustapha, a building worker, about taxis which refuse to come to the bidonville, in Hervo and Charras, Bidonvilles, p.267.

${ }^{43}$ Comment of police officers in Nanterre, 29 October 1961, in Hervo, Chroniques du bidonville, p.224.

${ }^{44}$ Interview with Lahoussine, a lorry driver in a construction company, in Hervo and Charras, Bidonvilles, p.182.

${ }^{45}$ Hervo and Charras, Bidonvilles, p.32.

${ }^{46}$ Interview with Lakhdar, Hervo and Charras, Bidonvilles, p.84. See, also, interview with Khadidja, wife of Miloud (a cement mixer driver from Casablanca), living in La Folie, on being refused credit on ground of their address, p.141.

47 'La petite maison garde la préférence de 80\% des Français', Le Parisien libéré, 11 June 1963, p.5.

48 'La promiscuté qu'ils subissent et les dangers qui les guettent,' in 'Dans un baraquement du répugnant bidonville de Nanterre, 3 enfants ont été brulés vifs', Le Parisien libéré, 26 March 1966, p.2. ${ }^{49}$ Alain Rey (ed.), Le Robert: dictionnaire historique de la langue française, 3 vols (Paris: Le Robert, 1998), III, 3768.

${ }^{50}$ See Alan Gilbert, 'The Return of the Slum: Does Language Matter?', International Journal of Urban and Regional Research, 31, 4 (2007), pp.697-713.

${ }^{51}$ See for example: 'Ces “Cours des Miracles" qui déshonorent la banlieue de grandes cités,' (These "Miraculous Courtyards" that dishonour the suburbs of great cities), in 'Dans un baraquement du répugnant bidonville de Nanterre, 3 enfants ont été brulés vifs', Le Parisien libéré, 26 March 1966, p.2.

${ }^{52}$ Kristeva, 'Approaching abjection', p.233.

${ }^{53}$ Interview with Lakhdar, in Hervo and Charras, Bidonvilles, p. 84.

54 'Maison de la Radio' episode of Edition spéciale, 5 September 1963.

${ }^{55}$ Interview with Lahoussine, in Hervo and Charras, Bidonvilles, p.184.

${ }^{56}$ Interview with Lahoussine, in Hervo and Charras, Bidonvilles, p.193.

${ }^{57}$ Kristeva, 'Approaching abjection', p.237.

${ }^{58}$ Les Immigrés en France, dir. Robert Bozzi.

59 'Les “bidonvilles" seront rasés et remplacés', Le Parisien libéré, 4 February 1966, p.3

${ }^{60}$ Guy Muller. 'Le relogement de plusieurs centaines d'Algériens pose de délicats problèmes à Chévilly-Laure et à L'Haÿ-les-Roses', Le Monde, 10 June 1965, p.7.

${ }^{61}$ 'Les riverains des bidonvilles pourront être expropriés', Le Parisien libéré, 26 May 1966, p.3. See also Daniel Champigny, Guide pratique des expropriations (Paris: Europa, 1967), p.42.

62 'L'opération "anti-bidonville" du gouvernement doit permettre de reloger, en 3 ans, plus de 60000 personnes', Le Parisien libéré, 26 March 1966, p.2.

63 'Les riverains des bidonvilles pourront être expropriés', Le Parisien libéré, 26 May 1966, p.3.

${ }^{64}$ Alexis Vibert-Guigue, Aux temps des chemins de grue. Chronique des années de béton, 1953-1993

(Paris: Editions des Alpes, 1993), pp.203-204.

65 'Informations diverses', Le Monde, 14 June 1967, p.9. 
${ }^{66} \mathrm{See}$, for example, shots of wooden shacks on the edge of a housing estate in Nanterre in the television documentary 'Grandes banlieues et petits loubards' episode of Les Mercredis de l'Information, TF1, 7 October 1981.

${ }^{67}$ Hervo and Charras, Bidonvilles, p.9.

${ }^{68}$ See, for example, the account by Abdallah, in Hervo and Charras, Bidonvilles, p.232. 